\title{
PENYULUHAN DAN PEMERIKSAAN TES HIV PADA IBU HAMIL DI KLINIK DINCE SAFRINA, SST
}

\author{
Berliana Irianti, S.Si.T, M.Keb ${ }^{(1)}$, Widya Juliarti ${ }^{(2),}$ Yuliana Novita $^{(3)}$ \\ STIKes Hang Tuah Pekanbaru \\ berlianairianti@htp.ac.id
}

\begin{abstract}
ABSTRAK
Acquired Immunodeficiency Syndrome (AIDS) is a set of clinical signs or symptoms in HIV sufferers due to opportunistic infections due to decreased immune system. HIV can be transmitted through unsafe sexual intercourse, sharing needles, and from HIV-infected pregnant women to their babies.

Indonesia is one of the countries in Asia that has HIV vulnerability due to the impact of changes in economic and social life. Pregnant women are very vulnerable to HIV transmission because babies can get HIV through the placenta, the delivery process, and when the mother is breastfeeding.

With the increasing cases of HIV transmission from mothers of children, the government is making various control efforts through the PPIA (Prevention of Mother-to-Child Transmission) program or PMTCT (Prevention of Mother-to-Child Transmission), which is carrying out HIV testing in early pregnancy and participating in the prevention program of mother-to-child transmission of HIV is a series of efforts to control HIV / AIDS cases

Based on the survey conducted, there were still many problems in the family who understood the importance of conducting HIV testing for pregnant women in Rumbai Pesisir District. Therefore, it needs to be addressed by holding counseling about HIV testing and examinations for pregnant women.
\end{abstract}

Keywords: socialization, HIV testing, pregnant women

\section{ABSTRAK}

Acquired Immunodeficiency Syndrome (AIDS) ialah sekumpulan tanda atau gejala klinis pada penderita HIV akibat infeksi oportunistik karena penurunan sistem kekebalan tubuh. HIV dapat menular melalui hubungan seksual yang tidak aman, pemakaian jarum suntik secara bergantian, dan dari ibu hamil yang terinfeksi HIV ke bayinya

Indonesia merupakan salah satu dari negara di Asia yang memiliki kerentanan HIV akibat dampak perubahan ekonomi dan kehidupan sosial. Ibu hamil sangat rentan dalam penularan HIV karena bayi dapat tertular HIV melalui plasenta, proses persalinan, dan saat sang ibu memberi ASI.

Sejalan dengan semakin meningkatnya kasus penularan HIV dari ibu keanak, pemerintah melakukan berbagai upaya pengendalian melalui program PPIA (Pencegahan Penularan HIV dari ibu ke anak) atau PMTCT (Prevention of Mother-to-Child Transmission), yaitu melakukan pemeriksaan HIV pada kehamilan secara dini dan mengikuti program pencegahan penularan HIV dari ibu ke bayi merupakan rangkaian upaya pengendalian kasus HIV/AIDS

Berdasarkan survey yang dilakukan masih banyak ditemukan masalah dalam hal dikeluarga tentang pentingnya melakukan tes HIV pada ibu hamil di Kecamatan Rumbai Pesisir. Maka dari itu, perlu diatasi dengan diadakannya sosialisasi/ penyuluhan tentang tes HIV dan pemeriksaan pada ibu hamil.

Kata Kunci: Sosialisasi, tes HIV, Ibu Hamil 
PENDAHULUAN

Human Immunodeficiency Virus merupakan golongan RNA spesifik yang menyerang sistem imun manusia, penurunan sistem imun pada orang yang terinfeksi HIV menyebabkan AIDS. Acquired Immunodeficiency Syndrome (AIDS) ialah sekumpulan tanda atau gejala klinis pada penderita HIV akibat infeksi oportunistik karena penurunan sistem kekebalan tubuh (Kemenkes RI, 2014). HIV dapat menular melalui hubungan seksual yang tidak aman, pemakaian jarum suntik secara bergantian, dan dari ibu hamil yang terinfeksi HIV ke bayinya (Efendi \& Makhfudli, 2009).

WHO (World Health Organization) sejak awal epidemi, hampir 78 juta orang telah terinfeksi virus HIV dan sekitar 39 juta orang telah meninggal karena HIV (WHO, 2013). Indonesia merupakan salah satu dari negara di Asia yang memiliki kerentanan HIV akibat dampak perubahan ekonomi dan kehidupan sosial. Penularan HIV umumnya terjadi akibat perilaku manusia, sehingga menempatkan individu dalam situasi yang rentan terhadap infeksi. Indonesia menjadi negara urutan ke 5 di Asia paling berisiko terkena HIV dan AIDS. Setiap tahun terjadi peningkatan jumlah kasus HIV dari tahun 2013 sebanyak 29.037 kasus menjadi 32.711 kasus pada tahun 2014 (Kemenkes, 2014).
HIV/AIDS merupakan isu kesehatan yang cukup sensitive untuk dibicarakan. Hal ini berkaitan dengan sifat yang unik dari penyakit ini. Selain kasusnya yang seperti fenomena gunung es, stigma dan diskriminasi pun juga banyak dialaim oleh penderita dan keluarganya. Tingginya stigma masyarakat terhadap penderita HIV/AIDS menyebabkan banyak perlakuan diskriminasi baik dalam pekerjaan, perawatan, pengobatan, pendidikan maupun dalam hal lainnya (Edi Suharto, 2015; 190) Ibu hamil sangat rentan dalam penularan HIV karena bayi dapat tertular HIV melalui plasenta, proses persalinan, dan saat sang ibu memberi ASI. Sedangkan untuk membuat sang bayi menjadi negative AIDS, selama ibu mengandung harus selalu di kontrol perkembangannya dan kepada sang ibu yang mengidap HIV disarankan untuk melakukan pengobatan antiretroviral, jika sang anak sudah lahir, ia pun harus mengonsumsi antiretroviral seumur hidup.

Lebih dari $90 \%$ anak pada tahun 2013 terinfeksi HIV didapatkan dari ibunya. Virus HIV dapat ditularkan dari ibu yang terinfeksi HIV ke anaknya selama kehamilan, saat persalinan dan menyusui (Kemenkes, 2013). Menurut Drake et al, (2014) masa kehamilan dan postpartum berisiko tinggi terhadap HIV. 
Risiko penularan dari ibu ke anak lebih tinggi diantara kejadian infeksi pada perempuan. Deteksi dan pencegahan kejadian HIV saat kehamilan atau postpartum harus diprioritaskan dan sangat penting untuk mengurangi penularan HIV dari ibu ke anak. Sejalan dengan semakin meningkatnya kasus penularan HIV dari ibu keanak, pemerintah melakukan berbagai upaya pengendalian melalui program PPIA (Pencegahan Penularan HIV dari ibu ke anak) atau PMTCT (Prevention of Mother-to-Child Transmission), yaitu melakukan pemeriksaan HIV pada kehamilan secara dini dan mengikuti program pencegahan penularan HIV dari ibu ke bayi merupakan rangkaian upaya pengendalian kasus HIV/AIDS dengan tujuan agar bayi yang dilahirkan dari ibu HIV positif terbebaskan dari HIV, kemudian ibu dan bayi tetap hidup dan sehat. (Kemenkes, 2011).

Konseling dan Testing Sukarela yang dikenal sebagai VCT (Voluntary Conseling and Testing) adalah proses konseling pra testing, konseling post testing, dan testing HIV secara sukarela yang bersifat rahasia dan secara lebih dini membantu orang mengetahui status HIV yang penting untuk pencegahan dan perawatannya. VCT penting bagi ibu hamil karena bertujuan pencegahan penularan HIV dari ibu ke anak, pencegahan dan manajemen klinis penyakit-penyakit yang berhubungan dengan HIV, pengendalian penyakit TBC (tuberculosis) serta dukungan psikologis dan hukum (Anastasya, 2010).

\section{METODE KEGIATAN}

Metode pengabdian masyarakat ini dilaksanakan dalam bentuk penyuluhan dan pelaksanaan tes dengan mengangkat tema "Penyuluhan dan Pelaksanaan Tes HIV Pada Ibu Hamil" dengan memberikan ceramah langsung, leaflet berisi materi dan gambar yang menarik serta Tanya jawab seputar Tes HIV Pada Ibu Hamil dan Melakukan Tes HIV Pada Ibu Hamil sehingga dapat dilakukan deteksi dini tentang HIV.

\section{HASIL DAN PEMBAHASAN}

\section{Hasil Pelaksanaan}

Kegiatan yang dilakukan dalam pengabdian kepada masyarakat ini dilaksanakan dalam beberapa tahapan yang diawali dengan pemberian penyuluhan terlebih dahulu tentang HIV, Cara Penularan dari Ibu Ke Bayi/ Anak, Gejala klinis, Kapan waktu yang tepat untuk melakukan tes, Konseling pra dan pasca tes HIV \& Menyikapi Hasil Tes HIV Kegiatan sosialisasi Tes HIV Pada Ibu Hamil ini telah dilaksanakan pada bulan Februari 2019 pada Ibu Hamil Di Klinik Pratama Hj. Dince Safrina, SST. 
Berdasarkan pengamatan selama kegiatan berlangsung, kegiatan pegabdian pada masyarakat ini memberikan hasil sebagai berikut :

$\square$ Meningkatnya pengetahuan dan pemahaman ibu hamil tentang Pemeriksaan HIV Pada ibu hamil diakibatkan karena kurangnya informasi atau pengetahuan. Hal ini dilihat dari kemampuan ibu-ibu hamil yang mampu menjawab pertanyaanpertanyaan yang diberikan pemateri.
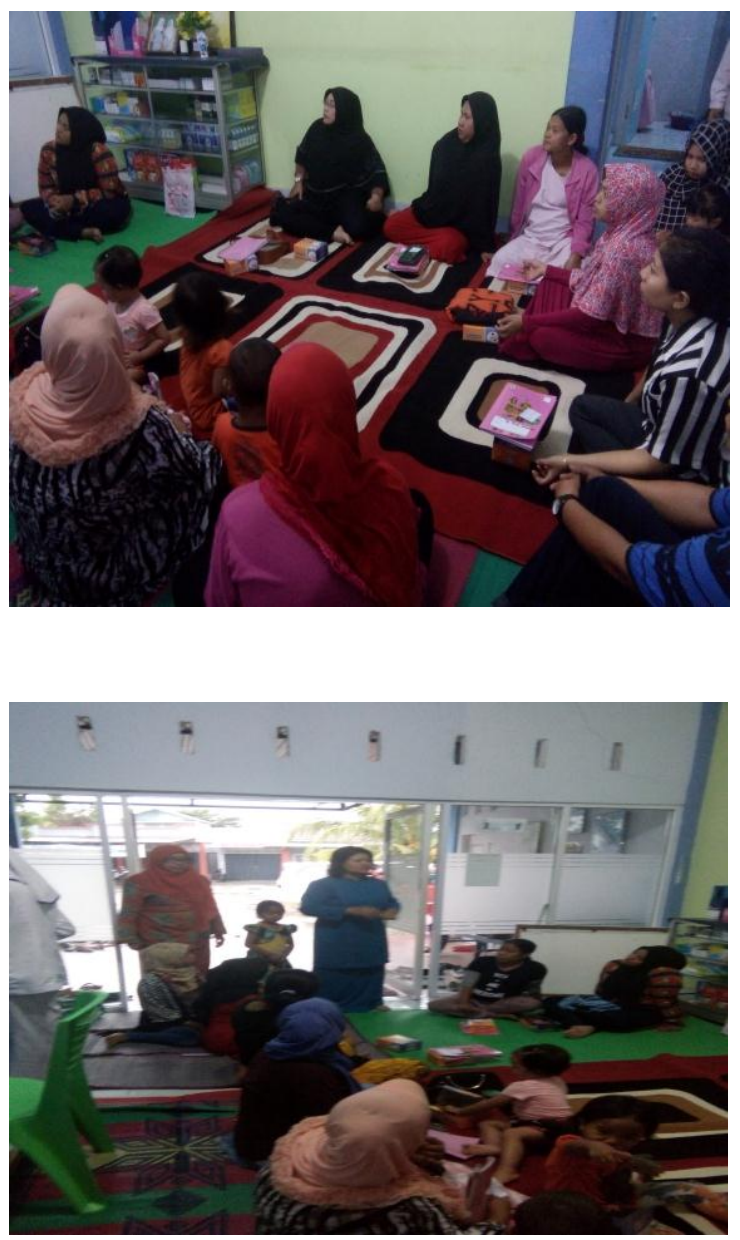

\section{Pembahasan}

Kegiatan penyuluhan tentang tes HIV pada Ibu hamil di Klinik Pratama Hj. Dince Safrina, SST berjalan dengan sangat baik. Hal ini terlihat dari antusias nya para ibu hamil yang hadir pada saat kegiatan berlangsung banyak para ibu yang bertanya menunjukkan rasa ingin tahu mereka terhadap materi yang disampaikan. Selama ini, pengetahuan ibu adalah selama kehamilan tidak memerlukan pemeriksaan lainnya selain pemeriksaan kehamilan, tetapi setelah mendengarkan penyuluhan ini para ibu yang memiliki bayi mengerti.

Dalam program PPIA terdapat kebijakan yang terintegrasi dalam pelayanan Kesehatan Ibu dan Anak (KIA) untuk melakukan tes HIV pada ibu hamil yang didasarkan pada tingkat prevelensi kasus HIV disuatu wilayah. Pada tingkat prevelensi kasus HIV dengan epidemi meluas dan terkonsentrasi, tes HIV dianjurkan untuk semua ibu hamil. Di daerah epidemi rendah tes HIV dianjurkan pada ibu hamil dengan indikasi perilaku berisiko. Tes HIV dilakukan bersamaan dengan pemeriksaan rutin antenatal di kunjungan pertama (K1) sampai menjelang persalinan (Kemenkes, 2014) 


\section{KESIMPULAN}

Disimpulkan bahwa angka pemeriksaan Tes HIV pada ibu hamil masih rendah. Disebabkan dari segi masyarakat, masih terdapat persepsi negatif mengenai tes HIV.

Meningkatnya pengetahuan dan pemahaman masyarakat tentang tes HIV pada ibu hamil tergantung pada kurangnya informasi atau pengetahuan dari tenaga kesehatan serta jarak rumah dengan fasilitas kesehatan yang terbilang cukup jauh. Hal ini dilihat dari kemampuan masyarakat yang mampu menjawab pertanyaan-pertanyaan yang diberikan pemateri.

\section{DAFTAR PUSTAKA}

1. Sari, A.P. (2015). Determinan Yang Mempengaruhi Stigma terhadap Orang dengan HIV/AIDS (ODHA) pada wanita pernah kawin usia 15-49 tahun di Indonesia. Skripsi. Universitas Indonesia.

2. Suhaimi, D., Savira, M., \& Krisnadi, S. R. (2009). Pencegahan Dan Penatalaksanaan Infeksi Hiv/Aids Pada Kehamilan. Jurnal Kedokteran
Umum.

http://journal.fk.unpad.ac.id/index.php /mkb/article/viewFile/184/pdf_68

3. Valerian, C.M., Kemara, K.P., \& Megadhana, I.W. (2010). Tatalaksana Infeksi Hiv Dalam Kehamilan. file://C:/Users/DELL/Downloads/487 3-1-7525-1-10-20130301.pdf. Diakses pada tanggal 15 Juni 2020.

4. Depkes RI. (2011). Profil Kesehatan Indonesia 2011. Jakarta: Depkes RI.

5. Kennedy, J. 2003. HIV in pregnancy and childbirth. London. Elsevier Science

6. Dewi, D.M.S.K., Wulandari, L.P.L., Wirawan. D.N. (2018). Determinan Sosial Kerentanan Perempuan Terhadap Penularan IMS Dan HIV. Jurnal. Program Studi S1 Kesehatan Masyarakat PSDKU Universitas Airlangga. $\quad \underline{\text { https://e- }}$ journal.unair.ac.id/JPHRECODE

7. WHO. (2017). HIV/AIDS: Data \& Statistic.http://www.who.int/hiv/data/e n/. Telah diakses pada 16 Juni 2020 